This item was submitted to Loughborough's Research Repository by the author.

Items in Figshare are protected by copyright, with all rights reserved, unless otherwise indicated.

\title{
Levelling the playing field? Towards a critical-social perspective on digital entrepreneurship
}

PLEASE CITE THE PUBLISHED VERSION

https://doi.org/10.1016/j.futures.2019.102438

\section{PUBLISHER}

(C) Elsevier

\section{VERSION}

AM (Accepted Manuscript)

\section{PUBLISHER STATEMENT}

This paper was accepted for publication in the journal Futures and the definitive published version is available at https://doi.org/10.1016/j.futures.2019.102438

\section{LICENCE}

CC BY-NC-ND 4.0

\section{REPOSITORY RECORD}

Dy, Angela Martinez. 2019. "Levelling the Playing Field? Towards a Critical-social Perspective on Digital Entrepreneurship". Loughborough University. https://hdl.handle.net/2134/38327. 


\section{Accepted Manuscript}

Title: Levelling the playing field? Towards a critical-social perspective on digital entrepreneurship

Author: Angela Martinez Dy

PII: $\quad$ S0016-3287(17)30429-9

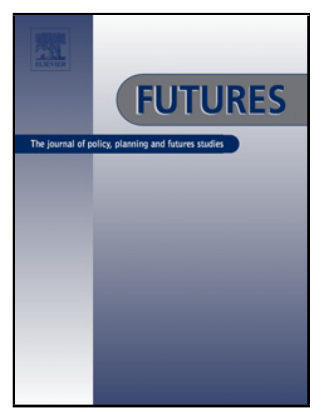

DOI: $\quad$ https://doi.org/10.1016/j.futures.2019.102438

Article Number: 102438

Reference: $\quad$ JFTR 102438

To appear in:

Received date: $\quad 15$ November 2017

Revised date: $\quad 9$ April 2019

Accepted date: $\quad 3$ July 2019

Please cite this article as: Dy AM, Levelling the playing field? Towards a critical-social perspective on digital entrepreneurship, Futures (2019), https://doi.org/10.1016/j.futures.2019.102438

This is a PDF file of an unedited manuscript that has been accepted for publication. As a service to our customers we are providing this early version of the manuscript. The manuscript will undergo copyediting, typesetting, and review of the resulting proof before it is published in its final form. Please note that during the production process errors may be discovered which could affect the content, and all legal disclaimers that apply to the journal pertain. 
Levelling the playing field? Towards a critical-social perspective on digital entrepreneurship

Submitted to the Special Issue of Futures on Digital Futures of Small Businesses and Entrepreneurial Opportunity

Angela Martinez Dy, a.dy@lboro.ac.uk

Loughborough University London

3 Lesney Avenue

The Broadcast Centre

Queen Elizabeth Olympic Park

London E15 2GZ UK'

\section{Abstract}

This conceptual paper critically analyses whether digital technologies have the potential to level the entrepreneurial playing field, and presents a more comprehensive and nuanced view of an increasingly significant yet underexplored phenomenon. Drawing upon three broad theoretical lenses: neoclassical economic entrepreneurship theory, cyberfeminist theories of technology and social embeddedness approaches to entrepreneurship, it critiques popular assumptions about digital entrepreneurship as an equalising force. It develops a novel critical-social perspective on digital entrepreneurship and an innovative typology of the landscape. Such an approach highlights a range of digital entrepreneurial activity and actors excluded from mainstream view, theorises the impact of technological requirements and socially distributed resources, and concludes that optimistic promises of success have been, and are likely to continue to be, realized primarily by those already in the top rungs of the social ladder.

KEYWORDS: digital, enterprise, entrepreneurship, cyberfeminism, intersectionality, social embeddedness 


\section{Highlights}

- Conceptual paper critically examining the potential for digital entrepreneurship and selfemployment to decrease social inequality

- Develops a critical-social perspective on digital entrepreneurship that critiques and complements extant views, and offers a novel typology of the landscape

- Uses three theoretical lenses: neoclassical economic entrepreneurship theory, cyberfeminist perspectives on technology, and social embeddedness approaches to entrepreneurship to critique claims about digital entrepreneurship as an equaliser

- Theorises and explains the effects of intersecting social hierarchies in the proliferation of digital microbusinesses and self-employment obscured by extant conceptualisations

- Argues that attention to the social aspects of digital entrepreneurship can provide a more nuanced and accurate understanding of the phenomenon 


\section{Introduction}

As contemporary social and technological developments have generated opportunities to combine resources, reach markets and create value in novel ways, attention to digital entrepreneurship (DE) as a phenomenon of research interest has increased (Nambisan, 2016; Palmer et al., 2018; von Briel et al., 2018). While not exclusively entrepreneurial, online trading is an extremely popular activity: $18 \%$ of UK internet users sell goods or services online (Prescott, 2017). Yet, despite the significance of the digital economy for entrepreneurship, the ways in which people entrepreneurially use digital technologies and create digital business ecosystems is still an under-explored, emergent area of scholarship (Giones and Brem, 2017; Sussan and Acs, 2017). In particular, despite a great deal of industry and policy focus on the future of the digital economy (Feldman et al., 2015; TechCity and Nesta, 2016), there is a persistent lack of knowledge about the wide range of people undertaking entrepreneurial activities online - their backgrounds, activities, and experiences - especially outside of high tech or deep tech sectors. It is the aim of this paper to complement, critique and extend the prevailing technological and economic-based perspectives on DE from a critical, sociological, and intersectional feminist point of view.

Digital entrepreneurship as a career choice features strongly within popular discourse beyond academia, with the simple Google search 'start an online business' producing over 7.4 billion results (June 2019). Not only is it portrayed as an affordable and accessible route for people to become self-employed, create new ventures, and build economic resilience (Accenture, 2014; Etsy, 2013), but also a means by which individuals can become entrepreneurially active, achieve work-life balance or increase work satisfaction while creating jobs for themselves and others in uncertain economic times (Duffy, 2017; Mallett and Wapshott, 2015). In a typical example of such discourse, popular handicraft sales platform Etsy characterises their sellers as 'Internet-enabled entrepreneurs who are building businesses on their own terms - prioritizing flexibility and independence over rapid growth, and using Etsy income to build resilience in the face of declining job security' (Etsy, 2013: 2). Such messages are influential with policymakers, and publicly endorsed by prominent industry organisations and their representatives (Federation of Small Businesses, 2011; Genachowski, 2011; Schmidt, 2011). Notably, the rhetorical claims about DE appear to be aimed particularly at populations marginalised by traditional forms of entrepreneurship or 
disadvantaged by standard employment structures. Women, especially mothers, people of colour, disabled people, the unemployed, retired, the aging and the young are all encouraged to build businesses online, where it is asserted that 'e-commerce is for anyone' (Quarton, 2014), including those who lack the resources required to create brick-and-mortar ventures. In another popular media example, a Google Chrome advertisement campaign claims 'The Web is what you make it,' featuring the rags-to-riches story of a mother-turned-entrepreneur who overcame a lack of resources and now influences the world of high fashion (Sowray, 2012). Taken together, such assertions about the promise of digital technologies for entrepreneurial activity shape public imagination by conceptually constructing the Internet as a 'level playing field' in which ambitions of entrepreneurship are made possible.

In response, this conceptual paper offers an immanent critique of such claims, and of academic literature on DE more generally, by making explicit their heretofore implicit assumptions of the Internet as 'neutral' entrepreneurial platform, drawing upon three established theoretical lenses to do so. The objective of the paper is to examine the analytical tension between contrasting conceptions of the phenomenon of $\mathrm{DE}$, and illuminate the need for a more accurate conceptualization that is both broader and more nuanced. As such it contributes a novel and timely critique to the debate on digital entrepreneurship. The paper is structured as follows: first, it presents a novel definition and overview of the phenomenon of $D E$, focusing upon illustrative claims drawn from extant literature, popular and news media about its transformative potential for individuals and societies. Second, it develops a critique of the same in light of neoclassical economic entrepreneurship theory, intersectional cyberfeminist theories of Internet technology, and social embeddedness approaches to entrepreneurship. Finally, to address research gaps and advance debate, an innovative conceptual approach and typology are presented, offering a theoretical foundation for a critical and sociologically informed view of the phenomenon.

\section{Digital entrepreneurship: levelling the playing field?}

An extensive body of literature associates innovative entrepreneurial activity with job creation and economic growth (Acs, 2006; Shane and Venkataraman, 2000; Shepherd and Patzelt, 2015). As such, institutions and policymakers in many countries, including the United 
Kingdom, have attempted to stimulate economic benefits by encouraging underrepresented groups, such as women and young people, to create new entrepreneurial ventures (Federation of Small Businesses, 2011; Harding, 2007; Marlow and Swail, 2014). In the UK, both motivational campaigns and material investments are underway, such as government investment in broadband diffusion, and various seed funding programmes (Government Equalities Office, 2014; Tobin, 2013). There are some corresponding evidence of shifting patterns of entrepreneurial activity: for example, women's self-employment is a driving force in the UK labour market (Watson and Pearson, 2016) and is on the rise worldwide (LeBlanc, 2015). Yet, the overarching messages about entrepreneurship neither account for nor interrogate the diversity of nascent businesses and the wide disparities in returns. In particular, self-employed people are overrepresented at the highest and lowest ends of the income distribution spectrum (Carter, 2011: 43), an established trend that is likely to be reflected in the DE landscape as well. Nonetheless, the expectation that digital technologies and the Internet are the means by which new businesses will be formed is central to such initiatives and messaging (Accenture, 2014; Government Equalities Office, 2014).

Yet these expectations are founded upon conceptualisations that now are out of date, built upon key assumptions in DE literature that have persisted since its inception and are overdue for critique. Early technocentric conceptualisations in business and management literature were narrowly limited to the creation of new 'dot coms' (Mahadevan, 2000; Matlay and Westhead, 2005), in which the Internet was flattened and oversimplified into resource rather than context. It was depicted as potentially transformative yet socially neutral, needing only appropriate exploitation (Amit and Zott, 2001; Porter, 2001). Contemporary DE research is emergent and scattered across disciplinary boundaries (Davidson and Vaast, 2010; Nambisan, 2016; Palmer et al., 2018; von Briel et al., 2018), but is still predominantly technocentric and focused upon expected enterprise benefits (Chandra and Coviello, 2010; Standing and Mattsson, 2016; Zaheer et al., 2018). The dynamic and growing variety of DE activity (Chandra and Coviello, 2010; Giones and Brem, 2017; Hull et al., 2007) is still underexplored and undertheorized, and its interaction with social marginality and unequal resource distribution even less so. When marginality or disadvantage is addressed, a deficit model is often invoked (Ahl and Marlow, 2012), and marginalised people encouraged to learn to entrepreneurially exploit digital tools (Thompson Jackson, 2009). Such overemphasis on 
entrepreneurial agency leaves little room for the relevance of group social positionality and individual life course history (Anderson and Miller, 2003; Jayawarna et al., 2014), and how these contribute to the presence or absence of entrepreneurial resources such as human, social and financial capital. The sections that follow develop an immanent critique of the DE literature, in which implicit assumptions made in three key claims about DE are identified and subjected to an interdisciplinary critique using three theoretical perspectives. The final section presents a novel critical-social perspective on DE to advance understanding and debate.

\subsection{Claim 1: The Internet as neutral entrepreneurial space}

The growing predominance of entrepreneurialism in the public imagination (da Costa and Silva Saraiva, 2012; Du Gay, 2004) chronologically parallels advances in Information and Communication Technologies (ICT), such as the introduction of personal computers, and rising Internet use (Fairlie, 2006). Billionaire founders of digital empires Amazon, Facebook and Google, Jeff Bezos, Mark Zuckerberg, Sergey Brin and Larry Page, have become celebrity entrepreneurs and role models, while their companies and imitators continue to dominate culture and shape economic structures (Taplin, 2017). The culture of entrepreneurialism compels aspiring entrepreneurs to use digital platforms to build businesses based on their interests; however, the rarity of success stories, alongside the constraints of structural social norms, are not often a feature of such discourse (Duffy, 2017).

In this context, the public perception of DE builds on two implicit assumptions: that entrepreneurship is an unfailingly positive activity, and that the Internet is a neutral and meritocratic space in which entrepreneurial activity can flourish. Pro-DE rhetoric (Accenture, 2014; LeBlanc, 2015; Quarton, 2014) asserts that the Web facilitates entrepreneurship by universally lowering barriers to entry and enabling instant access to global markets. DE is presented as a simple and obvious path to both individual self-sufficiency and wider social prosperity based upon the pursuit of one's passions (Duffy and Pruchniewska, 2017; Etsy, 2013). It is assumed to enable small firms to compete with their larger counterparts; Google Executive Chairman Eric Schmidt writes: 'of the world's 90 million small businesses, only 25 percent have a website. There is untapped potential here, without question. Only the largest 
and wealthiest companies can afford to advertise on television, but any company can build its brand online' (2011, author's emphasis).

Beyond the questionable assertion that television advertisements are still the epitome of marketing communications in an digital economy, underpinning these and similar claims is the presumption that the digital context of the activity automatically enables the realization of entrepreneurial potential. If the Internet is an open space in which a player of any size can compete with the 'largest and wealthiest', this implies an assumption that it is a positive or at least neutral space for entrepreneurship - a purportedly 'level playing field.' This echoes critical arguments regarding the similar presentation of entrepreneurship itself as an unfailingly positive, meritocratic and agential route to social progress, the success or failure of which is fully individualised (Blundel, 2007; Du Gay, 2004; Federici, 2019). Hence, the myth of entrepreneurial meritocracy, combined with the portrayal of the Internet as a neutral resource accessible and exploitable by all, has produced an overoptimistic depiction of the digital environment as the most meritocratic of entrepreneurial contexts, and DE as the most meritocratic of activities.

\subsection{Claim 2: Digital enterprise empowers marginalised people and economies}

Building upon this belief in a presumably meritocratic reward structure, academia, policy makers and popular media often present DE as an accessible solution to social disadvantage (Akalp, 2011; Genachowski, 2011; Thompson Jackson, 2009). It has been suggested that the virtual nature of exchanges can reduce the stigma experienced by marginalised groups, reduce risk and help overcome high barriers to entry, enabling wider economic participation (Jome et al., 2006). This message is targeted specifically at marginalised people who experience structural barriers to employment and career progression, particularly mothers, retirees, disabled people, young people, and people of colour (Accenture, 2014; Genachowski, 2011; Whiting and Pritchard, 2018; Women Entrepreneurs UK, 2010). By this rhetoric, people from these groups and their intersections are encouraged to embrace entrepreneurship, empower themselves, and in turn, advance the economy. The un- and underemployed are expected, with the help of support programmes including business mentoring and digital literacy training, to be able to transform themselves into successful business owners and gain control of their economic futures 
(Thompson Jackson, 2009). Examples are found throughout academic literature, business and industry press, as well as amongst policymakers: management consultancy Accenture (2014) asserts that 'every young entrepreneur is now a digital entrepreneur' (2014: 7) and that the solution to widespread youth unemployment in $\mathrm{G} 20$ countries is removing barriers for young digital entrepreneurs to scale up their businesses. Former Chair of the US Federal Communications Commission, Julius Genachowski, at a national Minority Media and Telecom Council Broadband and Social Justice Summit, presented broadband access as a platform for economic growth and job creation, and a 'great equaliser' for lower-income Americans of colour: 'giving every American with an Internet connection access to a world of new opportunities that might have previously been beyond their reach, and expanding their opportunities to succeed and thrive in a digital economy' (2011).

This targeting of marginal groups with digital enterprise rhetoric builds upon established tendencies to promote entrepreneurship amongst historically disadvantaged populations (Fairlie, 2005). Internet technology is depicted as a novel means by which to enact enterprise; terms such as 'empowerment', 'great enabler', and 'great equaliser' are used liberally, along with the suggestion there is less discrimination in cyberspace (Jome et al., 2006; Martin and Wright, 2005). This appears to be a technology-centred rhetorical evolution of the encouragement of microenterprise that began in the 1970s, when microenterprise development programmes were lauded as strategies to alleviate poverty and overcome welfare dependency; whilst many small businesses have been created and strengthened, in many cases such programmes have commoditized social relationships, encouraged economic vulnerability and the proliferation of debt (Ehlers and Main, 1998; Federici, 2019; Midgley, 2015). Whilst emergent research on digital micro-entrepreneurs shows genuine innovation and intention to become sustainable (Wynarczyk and Graham, 2013). Little work problematises the potential for growth and profitability of most online businesses (Jarvis, 2010). However, evidence suggests that home-based online businesses requiring little startup capital often remain micro-businesses led by sole proprietors with constrained profitability (Thompson et al., 2009; van Gelderen et al., 2008). Because of hegemonic gender structures, these types of businesses are predominantly the provenance of women. 


\subsection{Claim 3: Women as the ideal beneficiaries of digital entrepreneurial opportunities}

Women in particular are a categorical group whose entrepreneurial propensity and potential is disadvantaged by gendered assumptions and stereotypes which map onto marked bodies (Ahl 2006; Marlow \& McAdam 2012; Author et al. 2017). They tend to have reduced access to entrepreneurial resources both material and cultural, such as start-up capital and entrepreneurial legitimacy (Marlow and Patton, 2005; Pines et al., 2010; Swail and Marlow, 2018). Although underrepresented globally in entrepreneurship activity (Kelley et al., 2014), numerous gendered motivations exist at both structural and individual levels for women to undertake entrepreneurship, including lack of better economic options, desire for self-determination, disproportionate responsibilities for care and housework, and blocked mobility within corporate structures (Hytti, 2010; McAdam, 2012). In particular, given the intrusion of domestic and caring responsibilities upon women's economic participation, the promises offered by digital entrepreneurial activity - working from home, flexibility and being one's own boss - seem particularly appealing, as DE appears to offer enable the potential work-family synergies sought by many women (Eddleston and Powell, 2012; Jome et al., 2006). Thus, it should not surprise that women comprise $88 \%$ of sellers on the Etsy platform, as compared to only $\mathbf{2 8 . 7 \%}$ of home-based business owners across the US; in response, the company identifies women sellers as key beneficiaries, asserting the platform enables them to 'create flexible businesses that fit their lives, balancing creative passions, need for income and family obligations' (Etsy, 2013: 3). Accordingly, the allegedly unbiased virtual context of the Web is expected to enable women to work flexibly, from home if desired, while at the same time neutralising the assumptions of entrepreneurial deficit with which they tend to be associated (Ahl and Marlow, 2012).

Furthermore, in the UK context the shrinking of the public sector under austerity has left many women under-resourced and unemployed, especially women of colour, who were disproportionately negatively affected (Emejulu and Bassel, 2015). While overall unemployment rates are low, low-wage precarious employment is growing; in this setting, home-based digital entrepreneurship is perceived as an 'effective and viable route for engaging women in the labour market and, hence contributing to revitalisation of local communities and regional economic development' (Wynarczyk and Graham, 2013: 452). Yet, as Jayawarna et al. (2014) note, the much-extolled promise of home-based work to provide 
flexibility, allowing actors to better integrate work and family responsibilities, is exaggerated; moreover, it perpetuates the gendered divisions of household labour that place women as primary caregivers. Duberley and Carrigan (2012) find that women owners of home-based businesses actually face longer working hours and lower earnings than in employment, as well as trading limitations, a lack of credibility and constrained growth. Despite the contributions of home businesses to economic development (Mason et al., 2011), locating businesses in the home often has a negative impact on legitimacy from the point of view of creditors, customers, community and family members (McAdam, 2012; Walker and Webster, 2004). In addition, Kelan (2009) argues that increased flexibility can intensify work and blur boundaries between work and the domestic sphere, particularly for those with primary caring responsibilities, who disproportionately tend to be women.

While the online environment may seem less discriminatory and thus more equal, this is contradicted by evidence from new media studies that because the Internet is no longer text-based as it was in the early days, photos and videos are now expected in the production of an authentic online presence (Daniels, 2009). Thus, embodied reality is inescapable: women's enterprise online is still undervalued and constrained by traditional femininity in a 'digital double bind' (Duffy and Pruchniewska, 2017: 843); women and girls frequently experience sexism and misogyny online in the form of cyber sexual harassment and abuse (Bates, 2013; Jane, 2014), and race and ethnicity are highly salient in online activity (Noble and Tynes, 2016; Smith-Prei and Stehle, 2016). This, alongside recent findings that globally, offline gender inequalities tend to be replicated online (Yunus, 2017), tend to be omitted from the discourse encouraging women's participation in online business activity. With little acknowledgement of these persistent structural inequalities, members of disadvantaged groups continue to be encouraged to take up entrepreneurship and use Internet technology to do so, in order to increase their economic participation, combat un- or under-employment, and benefit the wider economy.

\section{Viewing digital entrepreneurship critically through three theoretical lenses}

The claims presented here can be usefully problematised by examining the discourse on digital enterprise interdisciplinarily, through three distinct lenses: neoclassical economic entrepreneurship theory, cyberfeminist perspectives stemming from feminist science and 
technology studies, and a sociologically informed embeddedness approach to understanding entrepreneurship. These three lenses have been selected for the following respective reasons: first, economic entrepreneurship theory calls attention to DE activity beyond tech start-ups, second, cyberfeminist theory problematises and complicates the technological progress perspective that assumes digital entrepreneurship necessarily constitutes an improvement to traditional entrepreneurship, and finally, a sociological embeddedness approach highlights the variety of resource needs that underpin successful DE activity, explaining them in relation to social positionality.

\subsection{Widening the scope with neoclassical economic entrepreneurship theory}

Due to the longstanding association of entrepreneurship with positive economic outcomes, there exists a 'success bias' (Ruef et al., 2003) because of which entrepreneurial activity that has generated, or is aimed at generating, economic wealth is afforded primary legitimacy. The prevalence of this success bias within explorations of DE (Braguinsky et al., 2012; Kaplan and Malach-Pines, 2010; Mayer, 2008) has likely contributed to the retained focus on high-tech digital businesses, i.e. high potential value mass-market platforms and applications, and concomitant paucity of theory on the variety of other digital entrepreneurial activities (Daniel et al., 2015; Duffy et al., 2015; Luckman, 2013). Moreover, the orientation towards wealth creation hinders attention to the impacts of social disadvantage or marginality on entrepreneurial activities, leaving this area significantly underexplored. Entrepreneurship as a phenomenon is not homogenous, and includes a diverse range of activities and experiences (Acs, 2006; Wright and Marlow, 2012). Likewise, heterogeneity in the population of self-employed is acknowledged: actors may be divided into 'intrinsically entrepreneurial', 'economically marginal,' and 'managerial' based on the success-bias-based criteria of growth orientation and innovativeness (Hofstede et al., 2004). Yet, because of the distinct social and economic challenges disadvantaged or marginalised people face in growing their businesses, self-employment may for them be a useful marker of entrepreneurial orientation (Zickuhr and Smith, 2012). Marlow et al. (2008) argue that those lacking resources may use self-employment as a lower cost market entry strategy and remain self-employed for the duration, while individuals with higher resource capacity will move from self-employment into business incorporation. As such, self-employment may accommodate the weakest economic activity amongst the poorest population groups, while business incorporation can 
indicate a growth-oriented focus amongst the resource rich (Marlow et al., 2008). Therefore, it stands to reason that that marginalised individuals targeted by DE discourse who do enter the entrepreneurial sphere are likely to do so through self-employment, but due to the success bias, are afforded neither legitimacy nor visibility. However, in contemporary enterprise ideology and discourse (da Costa and Silva Saraiva, 2012), self-employment and entrepreneurship are often conflated, and particularly so for members of disadvantaged groups, whose lack of access to resources may prevent them from pursuing high-growth opportunities.

Contrary to popular rhetoric, neoclassical economic entrepreneurship theory does not assume that everyone in any group, disadvantaged or otherwise, can use entrepreneurship as a route to economic security, for 'only some subset of the population will discover a given opportunity' (Kirzner, 1973 as cited by Shane and Venkataraman, 2000: 221). Of the many people who aspire to entrepreneurship, few are able to succeed; the small business failure rate has been estimated at forty percent in the first year and ninety percent in the first ten years (Shepherd et al., 2000). Moreover, the classic Schumpeterian entrepreneur is understood as an extraordinary individual whose innovation produces tectonic market shifts, termed 'creative destruction' (1934). Thus, theory suggests not dramatic change in entrenched patterns of socioeconomic inequality, but rather, a host of failures and a subset of individual success stories, of which only very few may have a broad economic impact. Hence, despite appearing to be underpinned by economic theory, the logic that the Internet can act as an equaliser, resulting in widespread entrepreneurial success, in fact contradicts well-established arguments. Through this lens, it becomes evident that the efforts on the part of policymakers and industry champions to widely promote digital enterprise are, in reality, more likely to correlate to large numbers of people undertaking economically marginal self-employment, rather than the proliferation of high-growth, high-value digital ventures they appear to promote.

Moreover, it is a tenet of neo-classical economic entrepreneurship theory that the asymmetry of information and resources has a strong influence upon entrepreneurial success (Alvarez and Busenitz, 2001; Haynie et al., 2009; Shane and Venkataraman, 2000). Although the introduction of the Internet brought with it an expectation that it would cause the distribution of information to be more balanced and less asymmetrical, instead, there is a 
proliferation of information of all types, and a number of novel challenges for people navigating this 'information overload'. Thus, while it can be safely assumed that some kinds of information asymmetry have been ameliorated, key information crucial to the wealth creation aspects of digital entrepreneurial success is still guarded, accessible primarily by those high in the social strata, or whose social positionality permits them entrance into highly homophilic entrepreneurial teams and networks (Braguinsky et al., 2012; Wing-Fai, 2016). Thus, some people will obviously be more privileged than others in accessing the information, contacts and resources needed to succeed. Considering this, the paper now turns to a discussion of cyberfeminist perspectives on technological development, and the ways in which existing asymmetrical information and resource structures, identified as relationships of power, affect and are affected by technological change.

\subsection{Intersectional cyberfeminist critique of technological 'progress'}

A feminist science and technology studies (FSTS) lens counters dominant discourses about women, as a key example of a marginalised group, prospering writ large in the digital economy. Such a lens frames technological development in the context of a modernist legacy that regards technological change as progress, and as such, unfailingly positive (Wajcman, 2010). This explains how the Internet has come to be idealised as a setting for entrepreneurship. Cyberfeminism is a subset of FSTS that engages specifically with the effects of the Internet upon gendered power relations (Daniels, 2009). It challenges the notion of technological neutrality, arguing that because Internet technology is socially embedded, there is no purely digital or virtual economy (Sassen, 2002). As a result, the implications of technological development upon existing power relations, including those of gender and race, may be positive, negative, or a combination. Because the Internet and its applications are human creations, they will to a large extent reflect existing social stratification: Sassen notes that hierarchies and power relationships 'inscribe electronic space' (2002: 366). Conversely, the online environment will likely have social, political, economic and cultural implications for offline society, supporting Wajcman's assertion that it will be both a source and consequence of gendered power relations (2010). Although some cyberfeminists argue that ICTs hold potential to positively influence gender relations (Oleksy et al., 2012) it is generally understood that men's domination of science and technology has, in most contexts, continued (Alfrey and Twine, 2017; Wajcman, 2004; Wong, 2017). Socio-economic inequality 
tends to be reproduced or exacerbated online (Boyd 2009; Marwick 2014; Author et al. 2017), and girls and women use the Internet in complex ways that both resist and reinforce hierarchies of gender and race (Cummings and O'Neil, 2015; Daniels, 2009).

Initiatives aiming to address social inequality through technology should note that the digital technologies upon which the online environment relies are subject to both the effects of social hierarchies and the decisions of social actors, particularly tech developers (Lanier, 2011); a striking lack of diversity has been a recurrent issue in these populations (Alfrey and Twine, 2017; Wong, 2017). On the user side, those engaged in online activities are embedded in offline contexts, bringing their worldviews, knowledge, experiences and values to the online space (Kolko, 2000; Rybas and Gajjala, 2007). Thus, habitual practices undertaken online can lead to the unconscious enactment of embodied identities (Schultze, 2014), rendering them inescapable. This means that rather than offering a way to overcome negative or discriminatory ascriptions based on embodied characteristics such as gender and race, the visual culture of the Internet reproduces and complicates such characteristics, and the oppression and discrimination based upon them (Daniels, 2012: 699; Duffy et al., 2015). Yet this is poorly acknowledged in discussions about DE. Despite the diversity of Internet users, due to the invisibility and hegemonic dominance of whiteness (Ahmed, 2012), the Web continues to be perceived as a non-racial space in which the prototypical user is assumed to be white (Kettrey and Laster, 2014). In light of a wealth of evidence regarding the online reproduction of social inequality, it is curious that its effects on DE are rarely considered.

Nevertheless, it should be noted that the digital environment has had a number of positive effects. For example, it offers a means for enhanced communication and community building by women entrepreneurs, particularly through social media (Ukpere et al., 2014). This is particularly relevant in digitally-enabled societies where the suppression of women in the public sphere delimits opportunities for education and income generation (Cellan-Jones, 2016; Greene et al., 2013). Within specific Arab Middle East contexts, for example, homebased enterprise may offer women the chance to earn income, although formal selfemployment or waged employment is still not culturally acceptable (Al-Dajani and Marlow, 2013); such enterprise often takes place between women, facilitated via the online environment. Women's creation and use of digital spaces has the capacity to build selfconfidence, potentially offer some economic opportunities, and foster communication and 
community building (Cummings and O'Neil, 2015). Yet overall, the applications and implications of ICTs in social activity should be understood as profoundly gendered in ways that tend to disadvantage women (Duffy, 2017; Michota, 2013), in particular those who are multiply marginalised (Daniels, 2009).

A cyberfeminist lens explains the motivation for digital entrepreneurial entry beyond the rational choice paradigm of mainstream entrepreneurship theory (Mole and Roper, 2012). It emphasies not only issues of individual preference for certain job roles, but also the degree of industry or specialised technical knowledge needed to begin a high-tech venture, in conjunction with the dearth of women in the technology field in general - attributable not to individual capability levels, but social and environmental factors, such as implicit biases imposed in childhood, education and the workplace (Hill et al., 2010) that shape narrow understandings of the gender-technology relationship (Kelan, 2009). It highlights the ways in which organisations and technologies are gendered by design and association, which filters through into assumptions about job roles and their performances; the job roles that seem to be available are influenced by our gender identities as well as the gendered appearance of workplaces and technologies (Kelan, 2009: 29). It further explicates the ways in which fundamental socio-economic participation mechanisms are gendered, limiting women to crowded, low-value added sectors by both vertical and horizontal occupational segregation, such that they are usually under-represented in the higher-performing and masculinised science, engineering and technology (SET) sectors (Kelan, 2009; Marlow and McAdam, 2012; Wajcman, 2004).

Even women working in the technology sector are clustered in 'softer' and 'less technical' areas, such as marketing, design and consulting (Kelan, 2009; Mayer, 2008). This trend persists into women's digital enterprise activities: although large scale surveys and generalizable evidence are lacking, initial evidence suggests women digital entrepreneurs may be overrepresented as providers of feminised services and retailers of predominantly 'feminine' products (Forson \& Ozbilgin 2003; Jome et al. 2006; Author et al. 2017) that may be less associated with technology and more with femininity. This evolution of the longstanding assumption that feminised domestic activities are easily transformed into moneymaking ventures may actually lock women into sectors that are labour-intensive and generate little or no profit (Ehlers and Main, 1998; Hess, 2013; Mirchandani, 1999). To better 
understand the means by which such constraint occurs, the following section draws upon social embeddedness perspectives on entrepreneurship to examine how social positionality impacts upon entrepreneurial activities, and extends this argument to DE.

\subsection{Entrepreneurial implications of social embeddedness}

While social networks have long been acknowledged as relevant to entrepreneurial opportunity development and success (Kwon et al., 2013; Wang and Altinay, 2012), an emergent strand of entrepreneurship literature is based upon the idea of social embeddedness, or the notion that social networks are themselves part of wider social hierarchies. This suggests that certain social networks may enable or constrain entrepreneurial activity, as resource access is tied to locations within hierarchies. Though the ways in which people engage with social networks online vs offline may be different (Smith et al., 2017), such social stratification is found to be relevant to the DE context as well. For example, Wing-Fai (2016) identifies that in the Taiwanese context small new digital and technology enterprises rely on family support and close (offline) social networks, which means that few women are able to join the sector due to close social ties and homophilic tendencies of the predominantly male founding teams.

In the socially embedded, political, heterogenous, and unequal digital landscape (Terranova, 2004) numerous factors may prevent or hinder socially disadvantaged actors from using technology to build sustainable, scalable digital businesses. This includes lower access to home broadband Internet and digital literacy education for people of colour ( $O^{\prime}$ Neill, 2015; Zickuhr and Smith, 2012), the growing racial wealth gap (Dickerson, 2014), underrepresentation and pushing out of women in the SET sector (Kelan, 2009; Lien, 2015) and women and people of colour's experiences of entrepreneurship, of which resource constraint and limited access to capital is a key feature (Carter et al., 2015; Fairlie, 2005). Although groups historically disadvantaged by a lack of basic Internet access can use mobile devices to go online, their mobile Internet connections are subject to wireless providers who have the ability to control and restrict users and content, resulting in access that is separate and unequal (King, 2011). Furthermore, simple access on its own is ineffective; it must be complemented by the know-how needed to utilise the technology for the intended ends (Wajcman 1991; Author et al. 2017). 
Thus, contrary to popular assumptions, from a social embeddedness perspective, the Internet seems unlikely to serve as a great equaliser. Entrepreneurial activity relies on the accrual of certain key resources over the course of an individual's life - from families of origin, to education and employment (Jayawarna et al., 2014). As families of origin usually determine the socio-economic positions into which people are born, they have important implications for the development of human and social capital, which are highly relevant to entrepreneurial outcomes (Anderson and Miller, 2003). Combining this with the black feminist construct of intersectionality (Cho et al., 2013; Crenshaw, 1989; May, 2015) suggests that exclusionary categories of gender, race/ethnicity and class, alongside other social characteristics such as sexual orientation, citizenship and disability, are co-constituted and work in concert to produce complex experiences of oppression and/or privilege. Hence, locations within these and similar intersecting categories affect the accrual of material, social and cultural resources (Anthias, 2001), the presence or absence of which can constrain or enable the pursuit of entrepreneurial opportunities. A social embeddedness lens thus offers powerful explanations for why members of historically disadvantaged populations still face disproportionate structural challenges to economic stability and wealth creation, despite decades of being encouraged into self-employment (Ehlers and Main, 1998). Such challenges may include barriers to education, unemployment, underemployment plus difficulties funding and growing new ventures (Carter et al. 2015; Author et al. 2017; Ram et al. 2003). While anecdotal success stories of overcoming such structural challenges abound in popular media (e.g. Sowray, 2012), the fundamental way in which one's social position and life course affects resource access has not been substantially or dramatically altered with the advent of the Web.

This perspective therefore illuminates how entrepreneurial activity will be enabled by the effects of social privilege, or constrained by social marginality, and sometimes both simultaneously. Higher socio-economic positions are found to correspond with higher financial and human capital; entrepreneurs in these positions are more likely to be located at advantageous positions within networks (Anderson and Miller, 2003). In contrast, underresourced people in the UK context tend to avoid entrepreneurship except in cases where low income threatens further downward mobility, although such class-based pathways to entrepreneurship are complicated by gendered childcare responsibilities (Jayawarna et al., 
2014). There are, therefore, concentrations of privilege amongst successful entrepreneurs and their networks, further ensuring that access to resources, and the entrepreneurial activity they enable, is unequally distributed. This is supported by strong evidence of homophily amongst entrepreneurial founding teams (Ruef et al., 2003), characterised by close network ties and demographic homogeneity. Homophily serves as a 'uniquely social predictor of between-group variation in economic inequality', as it 'reflects a tendency for social groups to employ a "like-deserves-like" rule in the allocation of collective rewards' (Ruef, 2009: $57,82)$.

The relevance of this argument for the digital context is tellingly illustrated in recent evidence, where high-tech entrepreneurs and investors are found to be overwhelmingly white, male, and from the top of the employment strata (Braguinsky et al., 2012; British Business Bank, 2019; Dashti, 2010; Nussbaum, 2015). Globally, around 90\% of technology entrepreneurs are men (Startup Genome and Telefonica, 2012). Women are severely underfunded as venture founders, and though obviously not restricted to marginal activity, tend to predominate in such arenas as craft-based online businesses (British Business Bank, 2019; Etsy, 2013; Hess, 2013). From a social embeddedness perspective, these differences are not wholly the result of individual choice and agency, but are heavily shaped by structural social conditions. The next section draws together the arguments made thus far to produce a novel conceptualization of DE as a socially embedded process that, like offline entrepreneurship, tends to favour those who are positioned more highly across various social strata. As such, it has less potential to act as a social equaliser than it does to enable marginal self-employment on a mass scale.

\section{Towards a critical-social perspective on digital entrepreneurship \\ 4.1 Redefining digital entrepreneurship}

The above arguments illustrate the ways in which DE research would benefit from engaging more with interdisciplinary insights. Digital culture theorists hold that while the Internet - the electronic network of networks linking people and information through digital devices (Dimaggio et al., 2001) - is ostensibly a common space, it is politicised and dynamic, so can be 'neither homogenous nor equal' (Terranova, 2004: 254), and so should not be assumed to be a potential leveller. Nevertheless, the myth of digital entrepreneurial 
meritocracy and success through hard work persists, propagated by digital influencers (Vaynerchuk, 2015) and senior figures in the technology world alike (Graham, 2019). New mass-market technologies undoubtedly alter or shift the routines, practices, relationships, and boundaries of paid and unpaid work and labour, and the structures of political economy more widely (Glucksmann and Nolan, 2007; Nansen et al., 2010). Digital businesses are, in many ways, technically more accessible, contributing to market variety with lower costs of entry, based on a notion that start-up requires only 'a computer and an idea' (van Gelderen et al., 2008: 166). Their ability to offer spatial and temporal flexibility in work arrangements, which could increase capacity for people with significant caring responsibilities, tends to be especially appealing to women (Wynarczyk and Graham, 2013) and is a likely reason for the dramatic growth in UK women's part-time self-employment since the economic crisis of 2008 (Watson and Pearson, 2016). Nansen et al. (2010) note that in 'working homes', technologies support autonomy, control, and greater potential for multi-tasking, but blur boundaries between work and non-work time. Home-based, capital-light businesses are often constrained in terms of turnover, job creation and possibilities for growth, and for their founders are often insufficient as a revenue stream, with many owners reporting the need for a variety of income sources, including employment (Etsy, 2013; van Gelderen et al., 2008). A comprehensive contemporary understanding of DE cannot ignore such prevalent activity. It must include, but look beyond, high tech and deep tech start-ups, while also opening conceptual space for emergent forms of activity. To do so, it must consider how such entrepreneurship is embedded in the social world: factors that constrain or enable entrepreneurial processes - such as racial, gendered and socioeconomic positionality, and their subsequent impacts on resource accumulation over the life course (Anderson and Miller, 2003; Jayawarna et al., 2014) - will in some ways be present in DE.

Emerging work calls for the advancement of an entrepreneurial research agenda explicitly theorising concepts related to digital technologies (Nambisan, 2016; Sussan and Acs, 2017). While this is indeed necessary, so too is theorising that links the exercise of digital entrepreneurial agency to the intricacies of human social structures. Nambisan (2016) identifies the key aspects of the digital entrepreneurial environment as: digital platforms, architecture, and artefacts; however, this techno-centric perspective does not consider the processual way entrepreneurship develops, nor the social context in which it is embedded 
(Steyaert, 2007; Watson, 2013). Furthermore, DE is itself a social process that benefits from offline human and social capital (Author et al., 2017). Lastly, as a form of socially embedded action, new and emerging forms of entrepreneurial activity (Goss, 2005), and that undertaken by more marginalised actors (Imas et al. 2012; Author et al. 2017), require theorizing as well.

Thus, there is need for a new DE definition that attends to the technological, the social, and the economic, and is flexible enough to include latent and emergent digital entrepreneurial activity. The Information Studies (IS) literature offers one usefully broad definition: 'the pursuit of opportunities based on the use of digital media and other information and communication technologies' (Davidson and Vaast, 2010: 2). However, this may unintentionally include more traditional or bricks-and-mortar self-employment or entrepreneurship with ICT products; for example, mobile phone repair shops. Therefore, an updated DE definition is proposed: 'the socially embedded process by which digital artefacts, platforms and architecture are used to pursue novel sources of value creation through profitable exchange.' This definition not only builds upon previous work (Davidson and Vaast, 2010; Giones and Brem, 2017; Nambisan, 2016), but it also follows the lead of the entrepreneurship literature as it turns from the notion of the opportunity to the entrepreneurial process (Alvarez et al., 2013). While excluding enterprises without a significant digital component, it still encompasses a range of activities, including, but not limited to, niche and mass market e-retailers, application, game and platform developers, content creators such as digital influencers, professional gamers and webcam models, and online professional service businesses. It thus enables attention to the vast range of digital businesses that exist, including, but not limited to, technology start-ups (Daniel et al., 2015; Laudon and Traver, 2013).

\subsection{Dimensions of the critical-social approach to digital entrepreneurship}

There exists significant scope for a new critique of the Internet as a neutral and meritocratic context for entrepreneurship, and the development of a corresponding analytical approach. Such an approach would reveal that digital entrepreneurial activity is unequally distributed across society, and that actor positionality is likely to enable or constrain entrepreneurial activity within a heterogeneous and unequal Internet landscape. Whereas existing perspectives focus on certain dimensions of the phenomenon: a technology 
perspective on DE on digital artefacts, platforms, and infrastructure (Nambisan, 2016), a strategy perspective on digital business models (Palmer et al., 2018), an ecosystems perspective on institutions, agency, infrastructure, and users (Sussan and Acs, 2017) and the extent to which the digital environment is used (Hull et al., 2007), the novel critical-social perspective proposed here integrates and advances these insights. It does so by taking explicit account of the neoclassical economic, cyberfeminist, and social embeddedness perspectives outlined in this paper, and their implications for digital entrepreneurship, theorising four relevant dimensions - mode of exchange, technological skill and knowledge requirement, resource and investment requirement, and the scalability of the business - upon which each of the three lenses outlined, individually and in concert, offer critical insight. These dimensions have two elements in common: first, their emergence from an immanent critique of the digital entrepreneurship literature (critical), and second, the relevance of the social positionality of entrepreneurial actors to variance across the dimension (social). They thus form the basis of a novel critical-social approach for understanding digital entrepreneurship. Each dimension will now be explored in turn.

\subsubsection{Mode of exchange}

Viewing DE through a neoclassical economic lens widens the scope of visibility upon the phenomenon to include actors who were previously obscured. A range of economic activity is subsumed under the heading of entrepreneurship, from the arbitrageur who is simply alert to any profitable opportunities for exchange (Kirzner, 1973) to the hero whose innovative activity has the potential to shift macro-economic patterns (Schumpeter, 2010 [1942]). This spectrum of entrepreneurial activity extends from informal and ad-hoc on one end, to formal, corporate and institutionalized on the other. Applying this to the phenomena of digital entrepreneurship, informal activities include ad-hoc sale and re-sale on user-friendly platforms such as eBay and Gumtree, often a first step into digital entrepreneurial activity for many. This may, or may not, mature into a peer to peer (P2P) business, which are typically run by an individual, often self-employed as a sole trader - many 'marketplace' style businesses fit this description. Self-employed individuals may also sell their labour and expertise to companies via digital platforms in a consumer-to-business (C2B) modality. Finally, individuals may create new ventures which take on employees in the legal form of a registered corporation limited by shares or guarantee. 
However, public attention to digital entrepreneurship often excludes the first three modalities, with the focus predominantly on the emergence of new tech platforms competing to become 'unicorns' in the fourth, new venture creation (NVC) modality (Brown and Wiles, 2015; McNeill, 2016; Simon, 2016). The high visibility of these Schumpeterian entrepreneurial actors, teams and ventures is in keeping with the focus on assumed economic contributions of successful high-value corporations that is herein argued to characterize both research and discourse about entrepreneurship (Acs, 2006; Ruef et al., 2003). Theorising the relevance of the mode of exchange challenges the accepted notion of the Internet as an inherently level playing field for DE by revealing the diversity of entrepreneurial activity taking place online.

\subsubsection{Technological skill and knowledge requirement}

Adopting a cyberfeminist perspective on DE calls attention to a number of relevant questions for the field, namely: who has access to what kinds of technological knowledge and skills, in what ways this affects their capability to engage in $\mathrm{DE}$, and when they do engage, at what levels are they able to do so? Feminist theorists of technology, work, labour and entrepreneurship (Alfrey and Twine, 2017; Kelan, 2009; Marlow and Carter, 2004; Wajcman, 2010) point to horizontal and vertical occupational segregation that keeps women underrepresented in the technology industry and particularly the high-tech and management roles that support the development of the knowledge bases needed for successful tech startup. A recent report by the British Business Bank (2019) finds that in the UK, $26 \%$ of employees in digital industries are women, and only $35 \%$ of managerial positions are held by women. Alfrey and Twine (2017) find inequality regimes within the US tech industry that favours men, and marginalises conventionally feminine heterosexual women and black and dark skinned Latina women, as opposed to white and Asian women who are racially dominant in the field. Such disparities in employment are preceded by poor gender diversity in computing courses in higher education (Babes-Vroman et al., 2017). This evidence suggests that the development of technical knowledge and skill will, in these geographical contexts, be skewed in favour of those in the industry who occupy masculine, white and Asian social positionalities.

The unequal accumulation of this valuable human capital, or association with those who possess it, is thus argued to enable or constrain potential engagement in higher-potential 
value tech start-up activities, such as the development of, using Nambisan's (2016) terminology, new digital applications, platforms and infrastructure. This is in contrast to the production of digital artefacts: although these range from written, to visual, to video content, their production tends to be more user-friendly and/or easily accessible to a wider range of people. It is therefore evident that different types of digital businesses necessitate a spectrum of technological input, with more technologically intensive and higher potential value businesses requiring rarer and more valuable technical skills inaccessible to the majority of entrepreneurial actors, particularly the most marginalised.

\subsubsection{Resource and investment requirement}

A social embeddedness view on entrepreneurship encourages attention to resources, which in the case of digital entrepreneurship often hinge on external investment. Conceptualising DE on a mode of exchange continuum from ad-hoc online sales to the development of new high tech or deep tech ventures reveals that the side of the continuum closer to new venture creation requires much more resource and investment, with the typical process including external investment from business angels and venture capital (VC) companies (Brown and Wiles, 2015). Diverse founders face severe impediments to external investment, and the social homophily trend (Ruef et al., 2003) affects not only entrepreneurial founding teams, but investors as well: the same British Business Bank (2019) report identifies that $83 \%$ of UK VC deals were given to all-male founding teams, and all-female teams constituted just $4 \%$ of deals; at the same time, only $13 \%$ women on senior VC investment teams are women, and $48 \%$ have no women at all. Black women founders in particular are severely underfunded (Williams, 2017). Beyond the human capital of technological knowledge and skill, for these reasons the significant financial and social capital required to found more ambitious DE ventures is thus argued to be relatively inaccessible to the vast majority of current and potential digital entrepreneurs.

\subsubsection{Scalability}

The techno-economic (Hull et al., 1999) dimensions of DE activity are the aspects of the phenomenon that tend to be foregrounded in extant conceptualisations (Nambisan, 2016; Palmer et al., 2018; Sussan and Acs, 2017). It is accepted that the technological 
underpinnings of such activity, and indeed, the digital nature of many products themselves, enable unprecedented scalability and potential profitability, such that they have ushered in a new digital era in which the nature of work and economic exchange has been radically transformed (Colbert et al., 2016). However, by failing to attend to the various social dimensions introduced here, this one-dimensional viewpoint is limited in its explanatory capacity regarding who is able to successfully found easily scalable, highly profitable digital ventures, and which types of businesses are likely to gain traction and funding, and become the sought-after tech 'unicorns' (Simon, 2016). In contrast, when complemented by the additional social dimensions, it becomes clear that more physical types of digital entrepreneurial activity, such as many service-based businesses, will be necessarily limited by a technological inability to scale, reducing profitability potential and the likelihood of external investment. For example, certain entrepreneurial benefits enabled by the Internet - platform development, real-time version testing, and digital economies of scale, to name a few - will be more useful for the subsets of digital businesses in which the business model is mostly automated, the platform is the product or software is the service, the commodity is easily replicated, or various income streams (e.g. direct sales, subscriptions, and external ad revenue) operate simultaneously. In contrast, for businesses that use the digital environment to a lesser degree, such as handicraft-based micro-enterprises, or sole traders of professional services, the digital infrastructure may lower cost of sales and communications, but not labour, production or distribution. Moreover, while some entrepreneurs will work within the existing digital infrastructure, others will create new infrastructure altogether (Sussan and Acs, 2017), and can expect corresponding financial rewards. Thus, the field is divided into what Hull et al. (2007) call mild, moderate, and extreme digital businesses, where the more extreme can expect to grow their businesses primarily by scaling up or expanding electronically to a larger online customer base, while more mild users will likely be unable to pursue this strategy.

\subsection{Benefits of a critical-social perspective on digital entrepreneurship}

A critical-social perspective advances existing conceptualisations by stressing the social foundations of disparity between digital ventures. It accounts for diversity amongst digital entrepreneurs and directs analysis to how their activity is constrained or enabled by socially embedded dimensions. It further identifies that higher barriers to entry for more 
technology intensive, scalable and potentially profitable digital businesses all but eliminate them as a viable entrepreneurial option for disadvantaged people encouraged to use the Internet to ameliorate poverty, under- or unemployment (Author et al. 2017). The below table synthesises key literature from the three identified theoretical perspectives from which these dimensions are drawn, to form the basis of the critical-social approach here proposed. Such a perspective suggests that DE participation by entrepreneurial actors differently positioned across social strata is likely to be unequally distributed across these dimensions, an insight with the potential to lend significant explanatory power to the findings of future empirical research.

\section{[TABLE 1 ABOUT HERE]}

Building upon the outlined dimensions, and the thesis that existing conceptualizations of DE are based upon erroneous assumptions and thus overlook critical aspects of the phenomenon, a novel typology of DE is presented in Figure 1. The purpose of the typology is to illustrate the paper's argument by theorising the conceptual scope of DE activity. It calls attention to activities across multiple modes of exchange, requiring a range of resource and investment, technical knowledge and skill levels, and demonstrating varying potential for scalability.

\section{[FIGURE 1 ABOUT HERE]}

The model can be read as follows. Across the top are the different modes of entrepreneurial exchange people can engage in online, ranging from ad-hoc, peer-to-peer $(\mathrm{P} 2 \mathrm{P})$, consumer-to-business $(\mathrm{C} 2 \mathrm{~B})$, and new start-up ventures. Looking at this in combination with the resource and investment continuum along the bottom of the model, there are higher barriers to entry for each move to the right, as more intensive modes of exchange require more resource and investment, thus incurring more risk. Similarly, looking down the left side of the model, the technological knowledge and skill requirement increases for each move down, again introducing barriers to entry: more privileged entrepreneurial actors will have access to more advanced skills (Kelan, 2009; Marlow and Carter, 2004; Wajcman, 2010), or the ability to hire or outsource them into the business. Finally, the right side of the model illustrates the way in which some digital entrepreneurial ventures are less or more scalable 
than others, from the point of view of the individual entrepreneurial actors or teams who are undertaking the new venture creation. Because of the nature of the product or service itself, some businesses will be more able to exploit the benefits of technology to quickly scale and grow a user base and potentially monetise, while other businesses' scalability will be constrained. The model as a whole shows that those businesses that are highly digital and easily scalable also require the most technological knowledge and skill as well as the most resource and investment.

Within the cells, the bold headings name and categorise, non-exhaustively, types of DE activities, according to the mode of exchange, technological knowledge and skill, resource and investment required for them to be carried out successfully. The normal text offers names of specific platforms that are currently in use to carry out these types of activities, while the italicised text offers additional supporting detail to outline ways in which these activities are monetised. It should be noted that the platforms themselves are further examples of high tech or deep tech DE, and because most digital entrepreneurial actors will be platform users, not creators, the number of individuals enacting such activities will be more highly concentrated in the upper left hand regions of the model.

Thus, the typology addresses significant knowledge gaps by conceptualising a number of undertheorised aspects of the phenomenon of DE activity. First, it shows the range and diversity of activities, from ad-hoc trading, to self-employment, to tech venture startup. This constitutes a novel contribution to the literature which, by focusing predominantly on hightech start-ups or established technology companies (Nathan et al., 2013), has offered minimal attention to the various types of entrepreneurial activity enabled by the digital environment, and the myriad ways in which individuals are able to make money using the Internet, whether through informal or more formalised means (Chandra and Coviello, 2010; Dashti, 2010). Second, the use of continuums along the four dimensions differentiates it from previous 'flat' typologies by adding much-needed texture to the topography of the digital enterprise landscape, illustrating relevant ways in which it is 'heterogenous and unequal' (Terranova 2004: 154). These continuums illustrate the range of technological knowledge and skill, as well as resource and investment, required for entrepreneurial entry into the identified domains. Finally, the typology unequivocally shows that not all digital opportunities are created equal: conversely, there is a spectrum of scalability and thus potential for growth of 
the user base, which is related to the kind of opportunity pursued. In turn, this is, as the paper has argued, related to the social positionality of the individual entrepreneur or team undertaking the venture. Technological knowledge and skills, and resource and investment access, are unequally distributed across society according to various social hierarchies (Anthias, 2013; Wajcman, 2010) with corresponding effects on entrepreneurship in general, and technology entrepreneurship in particular (Braguinsky et al., 2012; Jayawarna et al., 2014). Therefore, these two dimensions serve in the typology as proxies for the effects of differential positioning in socio-structural hierarchies; in this way, it highlights the effects of uneven resource distribution on DE activity.

Overall, the typology contributes to an improved understanding of the digital entrepreneurial field, and the ways in which the use of technology itself does not serve as a leveller for entrepreneurial activity. Starting in the upper left-hand corner of the model, moving down and across the field, barriers to entry, risk and potential profitability increase; as such, those with higher social positionality are more likely to have greater access to more valuable opportunities. This is corroborated by Braguinsky et al. (2012) and Dashti (2010), who find that high-tech entrepreneurs tend to come from the top part of the employment strata and have more connections to powerful social networks. It is further supported by emerging evidence from industry suggesting that, for example, women entrepreneurs are overrepresented in the upper left-hand corners of the field (Etsy, 2013; Hess, 2013; Wynarczyk and Graham, 2013) and sorely underrepresented in the bottom right (British Business Bank, 2019; Nussbaum, 2015; Startup Genome and Telefonica, 2012). Although the typology has some limitations - for example, it is predominantly Western-centric, and does not address nor include activity from the Dark Web - it offers a considered theoretical foundation for future empirical research in other contexts, both geographical and virtual.

The critical-social perspective developed here complements, critiques and extends techno-centric and economic perspectives with sociological insights, and offers considerable explanatory power for the empirical realities of the DE phenomenon. By defining and conceptually framing the wide range of DE activities that exist, theorising who is most likely to engage in what type of activity, and how their activity and outcomes tend to be shaped by social positionality and resource access, it explains why the digital entrepreneurial activities of only some privileged actors are likely to be high-tech, and thus more easily high-value and 
high-growth (Braguinsky et al., 2012; Dashti, 2010). Notably, it presents an important counterpoint to extant theory that neglects the socially embedded aspects of the phenomenon by portraying digital technological developments as neutral and equally available to all. As such, it advances debate in the emerging body of work on DE, enabling better and more accurate theory on the future of an increasingly significant phenomenon.

\section{Conclusion}

This paper problematises popular assertions that DE has the potential to widely empower and liberate marginalised actors, and proposes a theoretical explanation for why such claims are unrealistic. Drawing upon neoclassical economic entrepreneurship theory, feminist arguments, and social embeddedness perspectives on entrepreneurship, it argues that despite the transformative potential of the Internet, the landscape of DE is still shaped by social patterns of privilege and disadvantage. The paper thus presents an analytical critique of the Internet as a neutral, meritocratic space for entrepreneurship by identifying a theoretical tension between the conception of the Internet as a place where entrepreneurial opportunity is equally available to all, and the numerous entrepreneurial barriers to entry arising from unequal access to socially distributed material and cultural resources, despite the activity's digital context. This echoes feminist theories on science and technology suggesting that as a socio-technical artefact, the online environment can and does reflect, reproduce, and potentially exacerbate offline social hierarchies.

The paper makes a number of novel conceptual and theoretical contributions: first, it synthesises three established theoretical lenses in an immanent critique of the extant literature, thereby advancing debate. Second, it offers a new and updated definition of DE that addresses processual, technological, social and economic aspects to more accurately capture the phenomenon. Third, it theorises a novel critical-social conceptual approach to the phenomenon that uses four dimensions - mode of exchange, technological knowledge and skill, resource and investment, and scalability - to differentiate between DE activities, account for their relationship to structural differences of privilege and oppression between entrepreneurial actors. Finally, it offers a broadly applicable, yet nuanced typology of DE activity based upon these four dimensions that reveals undertheorised barriers to entry and highlights the limitations of the popular notion of 'digital enterprise for all'. 
The implications of this argument for theory, policy and practice are significant. The current trend of encouraging DE as a means to social mobility and economic independence for marginalised and disadvantaged people may in fact be encouraging greater economic vulnerability. If the digital environment continues to be perceived as neutral and meritocratic, then failure can more easily be attributed to agential error rather than to structural barriers, which are not able to be overcome by simply increasing the output or quality of individual labour. Future work in the field should attend to the ways in which offline social positionality can enable or constrain digital entrepreneurial activity, and address the structural obstacles to business development, investment and sustainability for a variety of kinds of digital businesses, and the diverse entrepreneurs who undertake them.

\section{Funding}

This work was supported by a PhD scholarship at Nottingham University Business School, the Vice-Chancellor's Scholarship for Research Excellence.

\section{Acknowledgements}

The author would like to acknowledge the guidance of her PhD supervisors, the support of the special issue editors, and the constructive comments of colleagues and reviewers in the development of the ideas put forward in this paper.

\section{References}

Accenture (2014) The promise of digital entrepreneurs: Creating 10 million youth jobs in the G20 countries. Available at:

http://www.accenture.com/SiteCollectionDocuments/PDF/Accenture-Promise-DigitalEntrepreneurs-Creating-10-Million-Youth-Jobs-G20-Countries.pdf (accessed 18 October 2016).

Acs Z (2006) How Is Entrepreneurship Good for Economic Growth? Innovations: Technology, 
Governance, Globalization 1(1): 97-107. DOI: 10.1162/itgg.2006.1.1.97.

Ahl H (2006) Why Research on Women Entrepreneurs Needs New Directions.

Entrepreneurship Theory and Practice 30(5): 595-621.

Ahl H and Marlow S (2012) Exploring the dynamics of gender, feminism and

entrepreneurship: advancing debate to escape a dead end? Organization 19(5): 543562. DOI: $10.1177 / 1350508412448695$.

Ahmed S (2012) On Being Included: Racism and Diversity in Institutional Life. Durham and London: Duke University Press.

Akalp N (2011) Why Women Make Excellent Entrepreneurs in the Digital Age. Available at: http://mashable.com/2011/10/25/women-entreprenuers/\#iGu1JkE478qc (accessed 10 October 2016).

Al-Dajani H and Marlow S (2013) Empowerment and entrepreneurship: a theoretical framework. International Journal of Entrepreneurial Behaviour \& Research 19(5): 503524. DOI: 10.1108/IJEBR-10-2011-0138.

Alfrey L and Twine FW (2017) Gender-Fluid Geek Girls: Negotiating Inequality Regimes in the Tech Industry. Gender and Society 31(1): 28-50. DOI: 10.1177/0891243216680590.

Alvarez SA and Busenitz LW (2001) The entrepreneurship of resource-based theory. Journal of Management 27: 755-775. DOI: 10.1007/978-3-540-48543-8_10.

Alvarez SA, Barney JB and Anderson P (2013) Perspective-Forming and Exploiting Opportunities: The Implications of Discovery and Creation Processes for Entrepreneurial and Organizational Research. Organization Science, 24(1): 301-317.

Amit R and Zott C (2001) Value Creation in E-Business. Strategic Management Journal 22: 493-520. DOI: 10.1002/smj.187.

Anderson AR and Miller CJ (2003) 'Class matters': Human and social capital in the entrepreneurial process. Journal of Socio-Economics 32(1): 17-36. DOI: 10.1016/S10535357(03)00009-X.

Anthias F (2001) The material and the symbolic in theorizing social stratification: issues of 
gender, ethnicity and class. The British Journal of Sociology 52(3): 367-390. DOI: 10.1080/00071310120071106.

Anthias F (2013) Hierarchies of social location, class and intersectionality: Towards a translocational frame. International Sociology 28(1): 121-138. DOI: $10.1177 / 0268580912463155$

Babes-Vroman M, Juniewicz I, Lucarelli B, et al. (2017) Exploring Gender Diversity in CS at a Large Public R1 Research University. In: ACM SIGCSE Technical Symposium on Computer Science Education, 2017. DOI: https://doi.org/10.1145/3017680.3017773.

Barney JB, Wright M and Ketchen Jr. DJ (2001) The resource based view of the firm: Ten years after 1991. Journal of Management 27(6): 625-641. DOI: $10.1177 / 014920630102700601$.

Bates L (2013) Online abuse against women: 'free speech' is no justification. Available at: http://www.theguardian.com/lifeandstyle/womens-blog/2013/nov/08/online-abusewomen-free-speech (accessed 10 October 2016).

Blundel R (2007) Critical Realism: A Suitable Vehicle? In: Neergard H and Ulhoi. JP (eds) Handbook of Qualitative Research Methods in Entrepreneurship. Cheltenham: Edward Elgar, pp. 49-74.

Boyd D (2009) The Not-So-Hidden Politics of Class Online. Available at: http://www.danah.org/papers/talks/PDF2009.html (accessed 18 October 2016).

Braguinsky S, Klepper S and Ohyama A (2012) High-Tech Entrepreneurship. The Journal of Law and Economics 55(4): 869-900. DOI: 10.1086/666488.

British Business Bank (2019) UK VC and Female Founders. Available at: https://www.britishbusiness-bank.co.uk/wp-content/uploads/2019/02/British-Business-Bank-UK-VentureCapital-and-Female-Founders-Report.pdf (accessed 2 April 2019).

Brown KC and Wiles KW (2015) In Search of Unicorns: Private IPOs and the Changing Markets for Private Equity Investments and Corporate Control. Journal of Applied Corporate Finance 27(3): 34-49. 
Carter S (2011) The Rewards of Entrepreneurship: Exploring the Incomes, Wealth, and Economic Well-Being of Entrepreneurial Households. Entrepreneurship: Theory and Practice 35(1): 39-55. DOI: 10.1111/j.1540-6520.2010.00422.x.

Carter S, Mwaura S, Ram M, et al. (2015) Barriers to ethnic minority and women's enterprise: Existing evidence, policy tensions and unsettled questions. International Small Business Journal 33(1): 49-69. DOI: 10.1177/0266242614556823.

Cellan-Jones R (2016) The internet - not an equaliser. Available at:

http://www.bbc.co.uk/news/technology-35323122 (accessed 10 October 2016).

Chandra Y and Coviello N (2010) Broadening the concept of international entrepreneurship: 'Consumers as International Entrepreneurs'. Journal of World Business 45(3): 228-236. DOI: 10.1016/j.jwb.2009.09.006.

Cheah HB (1990) Schumpeterian and Austrian entrepreneurship: Unity within duality. Journal of Business Venturing 5(6): 341-347.

Cho S, Crenshaw K and McCall L (2013) Toward a Field of Intersectionality Studies: Theory, Applications, and Praxis. Signs: Journal of Women in Culture and Society 38(4): 785810.

Clark DN and Douglas H (2010) Micro business: Characteristics of home-based business in New Zealand. Small Enterprise Research 17(2): 112-123. DOI: 10.5172/ser.17.2.112.

Colbert A, Yee N and George G (2016) The Digital Workforce and the Workplace of the Future. Academy of Management Journal 59(3): 731-739. DOI: $10.1145 / 1227846.1227847$.

Crenshaw K (1989) Demarginalizing The Intersection Of Race and Sex: A Black Feminist Critique Of Antidiscrimination Doctrine, Feminist Theory And Antiracist Politics. University of Chicago Legal Forum 1989(8): 139-167.

Cummings C and O'Neil T (2015) Do digital information and communications technologies increase the voice and influence of women and girls? A rapid review of the evidence. Available at: https://www.odi.org/sites/odi.org.uk/files/odi-assets/publications- 
opinion-files/9622.pdf (accessed 10 October 2016).

da Costa A and Silva Saraiva LA (2012) Hegemonic discourses on entrepreneurship as an ideological mechanism for the reproduction of capital. Organization 19(5): 587-614. DOI: $10.1177 / 1350508412448696$.

Daniel EM, Domenico M Di and Sharma S (2015) Effectuation and home-based online business entrepreneurs. International Small Business Journal 33(8): 799-823. DOI: $10.1177 / 0266242614534281$.

Daniels J (2009) Rethinking Cyberfeminism(s): Race, Gender, and Embodiment. WSQ: Women's Studies Quarterly 37(1 \& 2): 101-124. DOI: 10.1353/wsq.0.0158.

Daniels J (2012) Race and racism in Internet Studies: A review and critique. New Media \& Society 15(5): 695-719.

Dashti Y (2010) Social networks and high-technology entrepreneurs: the power of networks and how to put it to use. In: Malach-Pines A and Özbilgin M (eds) Handbook of Research on High-Technology Entrepreneurs. Cheltenham: Edward Elgar, pp. 347-356.

Davidson E and Vaast E (2010) Digital entrepreneurship and its sociomaterial enactment. Proceedings of the Annual Hawaii International Conference on System Sciences: 1-10. DOI: 10.1109/HICSS.2010.150.

Dickerson M (2014) The Economic Recovery in Black, White, and Brown. Available at: http://www.huffingtonpost.com/mechele-dickerson/the-economic-recovery-in_b_5837664.html (accessed 10 October 2016).

Dimaggio P, Hargittai E, Neuman WR, et al. (2001) Social Implications of the Internet. Annual Review of Sociology 27: 307-36.

Du Gay P (2004) Against "Enterprise" (but not against "enterprise", for that would make no sense). Organization 11(1): 37-57.

Duberley J and Carrigan M (2012) The career identities of 'mumpreneurs': Women's experiences of combining enterprise and motherhood. International Small Business Journal 31(6): 629-651. DOI: 10.1177/0266242611435182. 
Duffy BE (2017) (Not) Getting Paid to Do What You Love: Gender, Social Media and Aspirational Work. New Haven and London: Yale University Press.

Duffy BE and Pruchniewska U (2017) Gender and self-enterprise in the social media age: a digital double bind. Information, Communication \& Society 20(6). Taylor \& Francis: 843-859. DOI: 10.1080/1369118X.2017.1291703.

Duffy BE, Hund E, Hearn A, et al. (2015) 'Having it All' on Social Media: Entrepreneurial Femininity and Self-Branding Among Fashion Bloggers. Social Media+ Society 1(2): 111. DOI: 10.1016/j.chb.2015.08.026.

Eddleston K and Powell GN (2012) Nurturing Entrepreneurs' Work-Family Balance: A Gendered Perspective. Entrepreneurship Theory and Practice 36(3): 513-541.

Ehlers TB and Main K (1998) Women and the False Promise of Microenterprise. Gender \& Society 12(4): 424-440. DOI: 10.1177/089124398012004004.

Emejulu A and Bassel L (2015) Minority women, austerity and activism. Race and Class 57(2): 86-95. DOI: 10.1177/0306396815595913.

Etsy (2013) Redefining Entrepreneurship : Etsy Sellers ' Economic Impact.

Fairlie RW (2005) Entrepreneurship among Disadvantaged Groups: An Analysis of the Dynamics of Self-Employment by Gender, Race, and Education. In: Parker SC, Acs ZJ, and Audretsch DR (eds) Handbook of Entrepreneurship. Kluwer Academic Publishers.

Fairlie RW (2006) The Personal Computer and Entrepreneurship. Management Science 52(2): 187-203. DOI: 10.1287/mnsc.1050.0479.

Federation of Small Businesses (2011) Government must increase the number of female entrepreneurs to grow the economy, says FSB. Available at: http://www.fsb.org.uk/news.aspx?REC=6990 (accessed 5 April 2017).

Federici S (2019) Re-Enchanting the World: Feminism and the Politics of the Commons. Oakland, CA: PM Press.

Feldman M, Kenney M and Lissoni F (2015) The New Data Frontier: Special issue of Research Policy. Research Policy 44(9). Elsevier B.V.: 1629-1632. DOI: 
10.1016/j.respol.2015.02.007.

Forson C\& and Ozbilgin M (2003) 'Dotcom' Women Entrepreneurs in the UK. The international journal of entrepreneurship and innovation: 13-24.

Genachowski J (2011) Prepared Remarks of Chairman Julius Genachowski, Federal Communications Commission. Washington, DC, USA.

Giones F and Brem A (2017) Digital Technology Entrepreneurship: A Definition and Research Agenda. 7(5): 44-51. Available at:

https://papers.ssrn.com/sol3/papers.cfm?abstract_id=2984542.

Glucksmann M and Nolan J (2007) New technologies and the transformations of women's labour at home and work. Equal Opportunities International 26(2): 96-112. DOI: $10.1108 / 02610150710732186$.

Goss D (2005) Schumpeter's legacy? Interaction and emotions in the sociology of entrepreneurship. Entrepreneurship: Theory and Practice 29(2): 205-218. DOI: 10.1111/j.1540-6520.2005.00077.x.

Government Equalities Office (2014) Female entrepreneurs set to benefit from superfast broadband. Available at: https://www.gov.uk/government/news/femaleentrepreneurs-set-to-benefit-from-superfast-broadband (accessed 24 February 2015).

Graham P @paulG (2019) 'The next time someone claims that starting startups is for rich kids, remind them that Airbnb happened because its founders literally could not pay their rent.' 19 May. 12:52AM.

Greene FJ, Han L and Marlow S (2013) Like Mother, Like Daughter? Analyzing Maternal Influences Upon Women's Entrepreneurial Propensity. Entrepreneurship: Theory and Practice 37(4): 687-711. DOI: 10.1111/j.1540-6520.2011.00484.x.

Harding R (2007) State of Women's Enterprise in the UK.

Hayek FA (1945) The use of knowledge in society. American Economic Review, 35(4): 519530.

Haynie JM, Shepherd D and McMullen J (2009) An Opportunity for Me? The Role of 
Resources in Opportunity Evaluation Decisions. Journal of Management Studies 46(3): $337-361$.

Hess A (2013) Etsy Touts the Economic Power of Its Small Business Owners-Even If They Make $\$ 100$ a Year. Available at:

http://www.slate.com/blogs/xx_factor/2013/11/08/etsy_economic_impact_report_ets Y_crafters_generate_895_million_in_annual.html (accessed 3 April 2019).

Hill C, Corbett C and St. Rose A (2010) Why So Few? Women in Science, Technology, Engineering, and Mathematics. Available at: http://www.eric.ed.gov/PDFS/ED509653.pdf.

Hofstede G, Noorderhaven N, Thurik R, et al. (2004) Culture's Role in Entrepreneurship: SelfEmployment Out of Dissatisfaction. In: Brown T and Ulijin. J (eds) Innovation, Entrepreneurship and Culture: The Interaction between Technology, Progress and Economic Growth. Cheltenham: Edward Elgar, pp. 162-203.

Hull CE, Hung YC, Hair N, et al. (2007) Taking Advantage of Digital Opportunities: A Typology of Digital Entrepreneurship. International Journal of Networking and Virtual Organisations 4(3): 290-303.

Hull R, Walsh V, Green K, et al. (1999) The Techno-Economic: Perspectives for Analysis and Intervention. The Journal of Technology Transfer 24(2): 185-195. DOI: 10.1023/A:1007803405567.

Hytti U (2010) Contextualizing entrepreneurship in the boundaryless career. Gender in Management: An International Journal 25(1): 64-81. DOI: $10.1108 / 17542411011019931$.

Imas JM, Wilson N and Weston A (2012) Barefoot entrepreneurs. Organization 19(5): 563585. DOI: $10.1177 / 1350508412459996$.

Jack SL and Anderson AR (2002) The effects of embeddedness on the entrepreneurial process. Journal of Business Venturing 17(5): 467-487. DOI: 10.1016/S08839026(01)00076-3. 
Jane EA (2014) 'Back to the kitchen, cunt': speaking the unspeakable about online misogyny. Continuum 28(4): 558-570.

Jarvis A-A (2010) Net profits: how to make an online fortune. Independent, 11 August.

Available at: http://www.independent.co.uk/life-style/gadgets-and-tech/features/netprofits-how-to-make-an-online-fortune-2048882.html.

Jayawarna D, Rouse J and Macpherson A (2014) Life course pathways to business start-up. Entrepreneurship and Regional Development 26(3-4): 282-312. DOI:

10.1080/08985626.2014.901420.

Jome LM, Donahue MP and Siegel LA (2006) Working in the uncharted technology frontier: Characteristics of women Web entrepreneurs. Journal of Business and Psychology 21(1): 127-147. DOI: 10.1007/s10869-005-9019-9.

Kaplan G and Malach-Pines A (2010) Women Serial High-Technology Entrepreneurs. In: Özbilgin AM-P and M (ed.) Handbook of Research on High-Technology Entrepreneurs. Cheltenham: Edward Elgar, pp. 333-344.

Kelan EK (2009) Performing Gender at Work. Houndmills: Palgrave-MacMillan.

Kelley D, Brush C, Greene P, et al. (2014) SPECIAL REPORT Women's Entrepreneurship.

Kettrey H and Laster W (2014) Staking territory in the 'World White Web': An exploration of the roles of overt and color-blind racism in maintaining racial boundaries on a popular web site. Social Currents 1(3): 257-274.

King J (2011) How Big Telecom Used Smartphones to Create a New Digital Divide. Available at: https://www.colorlines.com/articles/how-big-telecom-used-smartphones-createnew-digital-divide (accessed 3 April 2019).

Kirzner IM (1973) Competition and Entrepreneurship. Chicago: University of Chicago Press.

Kolko BE (2000) Erasing @race: Going White in the (Inter)Face. In: Kolko BE, Nakamura L, and Rodman GB (eds) Race in Cyberspace. New York and London: Routledge.

Kwon S-W, Heflin C and Ruef M (2013) Community Social Capital and Entrepreneurship. American Sociological Review 78(6): 980-1008. DOI: 10.1177/0003122413506440. 
Lanier J (2011) You Are Not a Gadget. New York: Random House.

Laudon K and Traver C (2013) E-Commerce 2013: Business, Technology, Society. Upper Saddle River, NJ: Pearson Prentice Hall.

LeBlanc C (2015) Why the Rise of DIY Business Tools Is Good for Women Business Owners. Available at: http://www.huffingtonpost.com/cat-leblanc/why-the-rise-of-diy-businesstools-is-good-for-women-business-owners_b_65447.

Lien T (2015) Why are women leaving the tech industry in droves? LA Times, 22 February. Available at: http://www.latimes.com/business/la-fi-women-tech-20150222story.html\#page=1.

Luckman S (2013) Gender, Craft and the Creative Economy: Home-based Cultural Work and the Etsy Mum. 3rd Global Conference on The Value of Work: ... (March 2013). Available at: https://www.inter-disciplinary.net/critical-issues/wpcontent/uploads/2013/07/luckmanvowpaper.pdf.

Mahadevan B (2000) Business Models for Internet based E-Commerce An Anatomy. Operations Management 42(4): 0-32. DOI: 10.4018/978-1-61520-611-7.ch035.

Mallett O and Wapshott R (2015) Making sense of self-employment in late career: understanding the identity work of olderpreneurs. Work, Employment \& Society 29(2): 250-266. DOI: 10.1177/0950017014546666.

Marlow S and Carter S (2004) Accounting for change: professional status, gender disadvantage and self-employment. Women in Management Review 19(1): 5-17. DOI: 10.1108/09649420410518395.

Marlow S and McAdam M (2012) Analyzing the Influence of Gender Upon High-Technology Venturing Within the Context of Business Incubation. Entrepreneurship: Theory and Practice 36(4): 655-676. DOI: 10.1111/j.1540-6520.2010.00431.x.

Marlow S and Patton D (2005) All credit to men? entrepreneurship, finance, and gender. Entrepreneurship: Theory and Practice 29(6): 717-735. DOI: 10.1111/j.15406520.2005.00105.x. 
Marlow S and Swail J (2014) Gender, risk and finance: why can't a woman be more like a man? Entrepreneurship and Regional Development. Taylor \& Francis. DOI: 10.1080/08985626.2013.860484.

Marlow S, Carter S and Shaw E (2008) Constructing female entrepreneurship policy in the UK: Is the US a relevant benchmark? Environment and Planning C: Government and Policy 26(2): 335-351. DOI: 10.1068/c0732r.

Martin LM and Wright LT (2005) No gender in cyberspace? Empowering entrepreneurship and innovation in female-run ICT small firms. International Journal of Entrepreneurial Behaviour \& Research 11(2, 2005): 162-178. DOI: 10.1108/13552550510590563.

Martinez Dy A and Marlow S (2017) Women entrepreneurs and their ventures: complicating categories and contextualising gender. In: Henry C, Nelson T, and Lewis K (eds) The Routledge Companion to Global Female Entrepreneurship. Cheltenham: Edward Elgar.

Martinez Dy A, Marlow S and Martin L (2017) A Web of opportunity or the same old story? Women digital entrepreneurs and intersectionality theory. Human Relations 70(3): 286-311. DOI: 10.1177/0018726716650730.

Marwick A (2014) Conform or fail: Social media's broken promise. New Scientist, May.

Mason CM, Carter S and Tagg S (2011) Invisible Businesses: The Characteristics of Homebased Businesses in the United Kingdom. Regional Studies 45(5): 625-639. DOI: $10.1080 / 00343401003614241$.

Matlay H and Westhead P (2005) Virtual Teams and the Rise of e-Entrepreneurship in Europe. International Small Business Journal 23(3): 279-302. DOI:

$10.1177 / 0266242605052074$.

May VM (2015) Pursuing Intersectionality, Unsettling Dominant Imaginaries. London and New York: Routledge.

Mayer H (2008) Segmentation and segregation patterns of women-owned high-tech firms in four metropolitan regions in the United States. Regional Studies 42(10): 1357-1383.

McAdam M (2012) Female Entrepreneurship. London: Routledge. 
McNeill D (2016) Governing a city of unicorns: technology capital and the urban politics of San Francisco. Urban Geography 37(4): 494-513. DOI:

10.1080/02723638.2016.1139868.

Michota A (2013) Digital security concerns and threats facing women entrepreneurs. Journal of Innovation and Entrepreneurship 2(1): 7. DOI: 10.1186/2192-5372-2-7.

Midgley J (2015) Microenterprise, global poverty and social development. International Social Work 51(4): 467-479. DOI: 10.1177/0020872808090240.

Mirchandani K (1999) Feminist Insight on Gendered Work: New Directions in Research on Women and Entrepreneurship. Gender, Work \& Organization 6(4): 224-235. DOI: 10.1111/1468-0432.00085.

Mole K and Roper S (2012) The Rational Choice Approach to Entrepreneurship. In: Mole K and Ram M (eds) Perspectives in Entrepreneurship: A Critical Approach. Houndmills: Palgrave MacMillan.

Nambisan S (2016) Digital Entrepreneurship: Toward a Digital Technology Perspective of Entrepreneurship. Entrepreneurship: Theory and Practice (414): 1-27. DOI: 10.1111/etap.12254.

Nansen B, Arnold M, Gibbs M, et al. (2010) Time, space and technology in the working home: An unsettled nexus. New Technology, Work and Employment 25: 136-154. DOI: 10.1111/j.1468-005X.2010.00244.X.

Nathan M, Rosso A, Gatten T, et al. (2013) Measuring the Uk's Digital Economy With Big Data. National Institute for Economic and Social Research. Available at: http://www.niesr.ac.uk/sites/default/files/publications/SIO24_GI_NIESR_Google_Repo rt12.pdf.

Noble SU and Tynes BM (2016) The Intersectional Internet: Race, Sex, Class, and Culture Online (Digital Formations). New York: Peter Lang Publishing.

Nussbaum A (2015) Britain's Future Startups Are Overwhelmingly White and Male. Wall Street Journal, 16 June. Available at: http://blogs.wsj.com/digits/2015/06/16/britains- 
future-startups-are-overwhelmingly-white-and-male/.

O’Neill G (2015) Tech's High Barrier to Entry for the Underprivileged. Available at:

https://medium.com/backchannel/techs-high-barrier-to-entry-for-the-underprivilegedda254356547d.

Oleksy W, Just E and Zapedowska-Kling K (2012) Gender issues in information and communication technologies (ICTs). Journal of Information, Communication and Ethics in Society 10(2): 107-120.

Palmer C, Kailer N and Kallinger FL (2018) Digital entrepreneurship : A research agenda on new business models for the twenty-first century International Journal of Entrepreneurial Behavior \& Research Article information : (September). DOI: 10.1108/IJEBR-06-2018-0425.

Pines AM, Lerner M and Schwartz D (2010) Gender differences in entrepreneurship. Equality, Diversity and Inclusion: An International Journal 29: 186-198. DOI: http://dx.doi.org/10.1108/02610151011024493.

Porter M (2001) Strategy and the Internet. Harvard Business Review 79(3): 62-78.

Prescott C (2017) Internet access - households and individuals: 2016. Available at: https://www.ons.gov.uk/peoplepopulationandcommunity/householdcharacteristics/h omeinternetandsocialmediausage/bulletins/internetaccesshouseholdsandindividuals/2 016.

Quarton S (2014) The Complete Beginner's Guide to eCommerce. Available at: http://prospress.com/beginners-guide-to-ecommerce/ (accessed 20 September 2017).

Ram M, Smallbone D, Deakins D, et al. (2003) Banking on 'break-out': Finance and the development of ethnic minority businesses. Journal of Ethnic and Migration Studies 29(4): 663-681. DOI: 10.1080/1369183032000123440.

Ruef M (2009) Classification and the Homogeneity of Social Groups * Classification and the Homogeneity of Social Groups. (December).

Ruef M, Aldrich HE and Carter NM (2003) The Structure of Founding Teams: Homophily, 
Strong Ties, and Isolation among U.S. Entrepreneurs. American Sociological Reveiw 68(2): 195-222. DOI: 10.2307/1519766.

Rybas N and Gajjala R (2007) Developing Cyberethnographic Research Methods for Understanding Digitally Mediated Identities. Qualitative Social Research 8(3): Article 35. Available at: http://www.qualitativeresearch.net/index.php/fqs/article/view/282/619.

Sassen S (2002) Towards a Sociology of Information Technology. Current Sociology 50(3): 365-88.

Schmidt E (2011) The internet is the path to Britain's prosperity; This country is still one of the world's leaders in technology innovation and inventions. The Daily Telegraph, 16 May. Available at: http://www.telegraph.co.uk/technology/internet/8515771/Theinternet-is-the-path-to-Britains-prosperity.html.

Schultze U (2014) Performing embodied identity in virtual worlds. European Journal of Information Systems 23(1). Nature Publishing Group: 84-95. DOI: 10.1057/ejis.2012.52.

Schumpeter JA (2010) Capitalism, Socialism, and Democracy. Oxon: Routledge.

Shane S and Venkataraman S (2000) The promise of entrepreneurship as a field of research. Academy of Management Review 25(1): 217-226.

Shepherd DA and Patzelt $\mathrm{H}$ (2015) The 'heart' of entrepreneurship: The impact of entrepreneurial action on health and health on entrepreneurial action. Journal of Business Venturing Insights 4. Elsevier: 22-29. DOI: 10.1016/j.jbvi.2015.08.001.

Shepherd DA, Douglas EJ and Shanley M (2000) New venture survival. Journal of Business Venturing 15(5-6): 393-410. DOI: 10.1016/S0883-9026(98)00032-9.

Simon JP (2016) How to Catch a Unicorn. An Exploration of the Universe of Tech Companies with High Market Capitalisation. JRC Science Hub. DOI: 10.2791/893975.

Smith-Prei C and Stehle M (2016) \#AwkwardPolitics: \#Technologies of \#Popfeminist \#Activism. Montreal and Kingston: McGill-Queen's University Press.

Smith C, Smith JB and Shaw E (2017) Embracing digital networks: Entrepreneurs' social 
capital online. Journal of Business Venturing 32(1). Elsevier Inc.: 18-34. DOI:

10.1016/j.jbusvent.2016.10.003.

Sowray B (2012) The Cambridge Satchel Company's starring role. The Daily Telegraph, 31 August. Available at: http://fashion.telegraph.co.uk/news-features/TMG9511851/TheCambridge-Satchel-Companys-starring-role.html.

Standing C and Mattsson J (2016) "Fake it until you make it": business model conceptualization in digital entrepreneurship. Journal of Strategic Marketing 4488(June). Routledge: 1-15. DOI: 10.1080/0965254X.2016.1240218.

Startup Genome and Telefonica (2012) Startup Ecosystem Report, Part 1. Available at: http://multisite-blog.digital.telefonica.com.s3.amazonaws.com/wpcontent/uploads/2013/01/Startup-Eco_14012013.pdf.

Steyaert C (2007) 'Entrepreneuring' as a conceptual attractor? A review of process theories in 20 years of entrepreneurship studies. Entrepreneurship \& Regional Development 19(6): 453-477. DOI: 10.1080/08985620701671759.

Sussan F and Acs ZJ (2017) The digital entrepreneurial ecosystem. Small Business Economics 49(1): 55-73. DOI: 10.1007/s11187-017-9867-5.

Swail J and Marlow S (2018) 'Embrace the masculine; attenuate the feminine'-gender, identity work and entrepreneurial legitimation in the nascent context. Entrepreneurship and Regional Development 30(1-2). DOI: 10.1080/08985626.2017.1406539.

Taplin J (2017) Move Fast and Break Things: How Facebook, Google, and Amazon Have Cornered Culture and What It Means for All of Us. Columbus: Little, Brown and Company.

TechCity and Nesta (2016) Tech Nation 2016: Transforming UK Industries. Available at: http://www.techcityuk.com/wp-content/uploads/2016/02/Tech-Nation-2016_FINALONLINE-1.pdf.

Terranova T (2004) Network Culture: Politics for the Information Age. London, UK, and Ann 
Arbor, USA: Pluto Press.

Thompson Jackson J (2009) Capitalizing on Digital Entrepreneurship for Low-Income Residents and Communities. W. Va. L. Rev 112: 187-198.

Thompson P, Jones-Evans D and Kwong C (2009) Women and home-based entrepreneurship: Evidence from the United Kingdom. International Small Business Journal 27(2): 227-239. DOI: 10.1177/0266242608100492.

Tobin L (2013) Young Entrepreneurs Net Funding Boost. The Independent, 3 January.

Ukpere CL, Slabbert AD and Ukpere WI (2014) Rising trend in social media usage by women entrepreneurs across the globe to unlock their potentials for business success. Mediterranean Journal of Social Sciences 5(10 SPEC. ISSUE): 551-559. DOI: 10.5901/mjss.2014.v5n10p551.

van Gelderen M, Sayers J and Keen C (2008) Home-based internet businesses as drivers of variety. Journal of Small Business and Enterprise Development 15(1): 162-177. DOI: 10.1108/14626000810850900.

Vaynerchuk G (2015) Are You Working Hard Enough? Available at: https://www.garyvaynerchuk.com/are-you-working-hard-enough/ (accessed 7 June 2019).

von Briel F, Recker J and Davidsson P (2018) Not all digital venture ideas are created equal: Implications for venture creation processes. Journal of Strategic Information Systems 27(4). Elsevier: 278-295. DOI: 10.1016/j.jsis.2018.06.002.

Wajcman J (2004) Technofeminism. MA: Polity Press.

Wajcman J (2010) Feminist theories of technology. Cambridge Journal of Economics 34(1): 143-152. DOI: 10.1093/cje/ben057.

Wajcman JCPP (1991) Feminism and Technology. Cambridge: Polity Press.

Walker E and Webster B (2004) Gender Issues In Home-Based Businesses. Women In Management Review 19(8): 404-412. 
Wang CL and Altinay L (2012) Social embeddedness, entrepreneurial orientation and firm growth in ethnic minority small businesses in the UK. International Small Business Journal 30(1): 3-23. DOI: 10.1177/0266242610366060.

Watson E and Pearson R (2016) Here to Stay: Women's self-employment in a (post) austerity era. Women's Budget Group. Available at: https://wbg.org.uk/wpcontent/uploads/2015/02/Here_to_stay_selfemployment_Briefing_Mar16.pdf.

Watson TJ (2013) Entrepreneurial action and the Euro-American social science tradition: pragmatism, realism and looking beyond 'the entrepreneur'. Entrepreneurship \& Regional Development 5626(December 2016): 16-33. DOI: 10.1080/08985626.2012.754267.

Whiting R and Pritchard K (2018) Reconstructing Retirement as an Enterprising Endeavor. Journal of Managment Inquiry. DOI: 10.1177/1056492618818773.

Williams BA (2017) The Tech Industry's Missed Opportunity: Funding Black Women Founders. Available at: https://www.fastcompany.com/40422830/why-the-techindustry-is-hurting-itself-by-not-funding-black-women-founders.

Wing-Fai L (2016) The strengths of close ties: Taiwanese online entrepreneurship, gender and intersectionality. Information Communication \& Society 19(8). Taylor \& Francis: 1046-1060. DOI: 10.1080/1369118X.2015.1069873.

Women Entrepreneurs UK (2010) Mumpreneurs: 'There are several fields open to mother entrepreneurs nowadays because of the Internet, but the success lies in the choosing.' Available at: http://www.womenentrepreneursuk.com/mumpreneurs.htm (accessed 11 January 2016).

Wong JC (2017) Segregated Valley: the ugly truth about Google and diversity in tech. The Guardian, 7 August. Available at:

https://www.theguardian.com/technology/2017/aug/07/silicon-valley-googlediversity-black-women-workers.

Wright $\mathrm{M}$ and Marlow S (2012) Entrepreneurial activity in the venture creation and development process. International Small Business Journal 30(2): 107-114. DOI: 
10.1177/0266242611432793.

Wynarczyk P and Graham J (2013) The impact of connectivity technology on home-based business venturing: The case of women in the North East of England. Local Economy 28(5): 451-470. DOI: 10.1177/0269094213491700.

Yunus M (2017) WWW Foundation: Offline Gender Inequalities Being Replicated Online. Available at: https://www.voanews.com/a/digital-gender-gap/4054666.html (accessed 3 October 2017).

Zaheer H, Breyer Y, Dumay J, et al. (2018) Straight from the horse's mouth: Founders' perspectives on achieving 'traction' in digital start-ups. Computers in Human Behavior (March). Elsevier Ltd. DOI: 10.1016/j.chb.2018.03.002.

Zickuhr K and Smith A (2012) Digital differences. Available at: http://www.english.illinois.edu/-people/faculty/debaron/482/482readings/PEW_Class.pdf (accessed 18 October 2016). 


\section{Figure captions}



Figure 1: Critical-Social Typology of Digital Entrepreneurial Activity 


\begin{tabular}{|l|l|l|l|}
\hline $\begin{array}{l}\text { Digital Entrepreneurship } \\
\text { Dimension }\end{array}$ & $\begin{array}{l}\text { Neoclassical Economic } \\
\text { Entrepreneurship Theory }\end{array}$ & $\begin{array}{c}\text { Cyberfeminist } \\
\text { Technology Theory }\end{array}$ & $\begin{array}{l}\text { Social Embeddedness } \\
\text { Perspective }\end{array}$ \\
\hline Mode of exchange & $\begin{array}{l}\text { Heterogeneity in self- } \\
\text { employed population } \\
\text { (Cheah, 1990) }\end{array}$ & $\begin{array}{l}\text { Social hierarchies and } \\
\text { power relations shape } \\
\text { digital activities and } \\
\text { experiences (Daniels, } \\
\text { 2009; Sassen, 2002) }\end{array}$ & $\begin{array}{l}\text { Homophily amongst } \\
\text { entrepreneurial } \\
\text { communities (Ruef et al., } \\
\text { 2003; Wing-Fai, 2016) }\end{array}$ \\
\hline $\begin{array}{l}\text { Technological } \\
\text { knowledge and skill }\end{array}$ & $\begin{array}{l}\text { Information asymmetry } \\
\text { (Hayek, 1945) }\end{array}$ & $\begin{array}{l}\text { Men and masculinity } \\
\text { continue to dominate in } \\
\text { science and technology } \\
\text { fields (Wajcman, 2010) }\end{array}$ & $\begin{array}{l}\text { Rarity of valuable human } \\
\text { and social capital } \\
\text { (Anderson and Miller, } \\
\text { 2003; Jack and } \\
\text { Anderson, 2002) }\end{array}$ \\
\hline $\begin{array}{l}\text { Resource and } \\
\text { investment requirement }\end{array}$ & $\begin{array}{l}\text { Resource asymmetry } \\
\text { (Alvarez and Busenitz, } \\
\text { 2001; Barney et al., } \\
\text { 2001) }\end{array}$ & $\begin{array}{l}\text { Socio-economic } \\
\text { inequality tends to be } \\
\text { reproduced or } \\
\text { exacerbated online } \\
\text { (boyd 2009; Marwick } \\
\text { 2014) }\end{array}$ & $\begin{array}{l}\text { Resources unequally } \\
\text { distributed across social } \\
\text { strata with effects on } \\
\text { entrepreneurship over } \\
\text { life course (Jayawarna et } \\
\text { al., 2014) }\end{array}$ \\
\hline Scalability & $\begin{array}{l}\text { Rarity of valuable } \\
\text { entrepreneurial } \\
\text { opportunities and } \\
\text { influence of resources in } \\
\text { opportunity pursuit } \\
\text { (Haynie et al., 2009) }\end{array}$ & $\begin{array}{l}\text { Technology may not } \\
\text { ameliorate the growth } \\
\text { constraints experienced } \\
\text { by many women } \\
\text { business owners (Clark } \\
\text { and Douglas, 2010) }\end{array}$ & $\begin{array}{l}\text { Technology-centric } \\
\text { opportunities are more } \\
\text { scalable but rarer and } \\
\text { less accessible } \\
\text { (Braguinsky et al., 2012; } \\
\text { Dashti, 2010) }\end{array}$ \\
\hline
\end{tabular}

Table 1: Critical-Social Dimensions of Digital Entrepreneurship 